\title{
Biotechnological methods of preservation of the grape gene pool in the in vitro collection
}

\author{
Natalia Doroshenko and Valentina Puzirnova \\ All-Russian Research Institute for Viticulture and Winemaking named after Ya.I. Potapenko - Branch \\ of Federal State Budget Scientific Institution «Federal Rostov Agricultural Research Center», 166 \\ Baklanovsky, Novocherkassk, Rostov region, 346421 Russia
}

\begin{abstract}
Annotation. The article shows the results of the improvement of meristem survival, its growth characteristics, shoot formation with the combined usage of apical meristems and the preparations such as Ribavirin, salicylic acid, Melafen, the antibiotic Cefotaxime. The research results demonstrate a decrease in the intensity of growth with the presence of sucrose, fructose, and sorbitol in the culture medium. The clarification of the parameters of the preparations application made it possible to increase the duration of nonstop storage of plants up to $8-10$ months.
\end{abstract}

\section{Introduction}

The problem of the conservation of plant biodiversity is acute all over the world. Classical methods can no longer cope with this task. The application of advances in biotechnology, in addition to the traditional methods of ex situ and in situ conservation of biodiversity, allows the sustainable management of genetic resources [1-2]. The most important achievement of biotechnology is the possibility of creating an in vitro culture bank for long-term storage of the plant gene pool [3-5].

The biotechnological research in the field of viticulture, which began in 1979-1987, is actively developing today [6-15].

The success of in vitro collection creation largely depends on the efficiency of introducing plant material into sterile culture. Therefore, the improvement of input methods is an important stage in our research. To increase the efficiency of long-term storage of the gene pool, it is necessary to free the plant material from pathogens and quickly multiply it [16]. The combination of cultivation of apical meristems with the chemotherapy makes it is possible to increase the healing effect and the reproductive rate of the healthy plants.

The purpose of the research is to improve the stage of initiation of grape meristems into in vitro culture, taking into account the varietal characteristics of mother plants, to develop ways to reduce the intensity of growth processes for the long-term non-stop storage of valuable grape varieties in the in vitro collection. 


\section{Materials and methods}

The research methodology meets generally accepted requirements. The place for the experiments is the laboratory of biotechnology of the All-Russian Research Institute of Viticulture and Winemaking named after named after Ya.I. Potapenko.

The method is based on the plant health improvement using the culture of apical meristems with the explant size of $0.1-0.2 \mathrm{~mm}$. The culture of meristems was supplemented with the inclusion of the antiviral preparations Ribavirin $(5-30 \mathrm{mg} / \mathrm{L})$, salicylic acid $(0.14$ $\mathrm{mg} / \mathrm{L})$, the growth regulator Melafen (10-5, 10-7, 10-9, 10-11\%.) and antibiotic Cefotaxime (50-300 mg).

To slow down the growth processes at the stage of micro grafting sucrose (5-90 g / L), fructose (5-60 g / L), and sorbitol (5-60, g / L) were added into the solid culture medium.

\section{Results and discussions}

The grape varieties Crystal and Platovsky were initiated into in vitro culture, the isolated apical meristems were planted on a culture medium containing Ribavirin, salicylic acid, Cefotaxime, Melafen.

In the Platovskiy variety, a higher survival rate was noted when the preparation Ribavirin and salicylic acid were added to the culture medium, however the development of meristems in these variants was slowed down - the size of the meristems were mainly $1-3 \mathrm{~mm}$. The development of meristems with the use of Melafen, Ribavirin and Cefotaxime occurred at a more intensive pace.

At the stage of proliferation, a higher productive regeneration is clearly visible in the Platovsky variety - 25 shoots compared to the Kristall variety - 14 shoots. There was a noticeable difference in the experimental variants. Most of the shoots were cut off in the Kristall variety in the variants with added Ribavirin and Cefotaxime, and as well in the Platovskiy variety in the variants with the combined use of Ribavirin with salicylic acid and Cefotaxime.

The growth regulator Melafen (10-7 and 10-11) and the antibiotic Cefotaxime at a concentration of $200 \mathrm{mg} / 1$ (Table 1) had a positive effect on the passage of the stage of initiation the meristems of the North Saperavi variety and their transition to the stage of proliferation.

Table 1. The introduction of meristems of the Saperavi severny variety into the culture

\begin{tabular}{|c|c|c|c|c|c|c|c|c|}
\hline \multirow[b]{2}{*}{ Variants } & \multicolumn{6}{|c|}{ Characteristics of the state of meristems, pieces } & \multirow{2}{*}{ 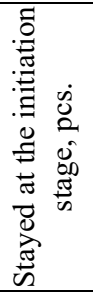 } & \multirow{2}{*}{ 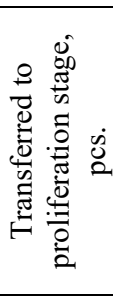 } \\
\hline & 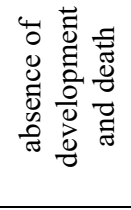 & 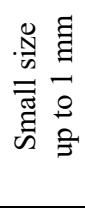 & 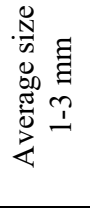 & 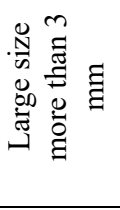 & 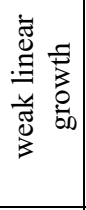 & 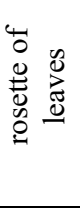 & & \\
\hline Control & - & 4 & 7 & 3 & - & - & 3 & - \\
\hline Cefotaxime 50 & 2 & 3 & 5 & 4 & - & - & 2 & - \\
\hline Cefotaxime 100 & 3 & 5 & 3 & 3 & - & - & 2 & 1 \\
\hline Cefotaxime 200 & - & 3 & 7 & 4 & - & - & 4 & 3 \\
\hline Melaphen 10-7 & - & - & 5 & 6 & 3 & - & 7 & 7 \\
\hline Melaphen 10-11 & 1 & - & 7 & 3 & 2 & 1 & 2 & 5 \\
\hline
\end{tabular}

The research of the initiation stage was continued on the varieties Tsvetochniy and Present. The experience with the Tsvetochnyi variety was characterized by a high survival 
rate of meristems - up to $90 \%$. The survival rate in the experiment on the Present variety was up to $84.5 \%$. The experiment showed that the antiviral drug Ribavirin does not have a negative effect on the development of meristems at a concentration of 5-30 mg / L, since their intensive growth was noted. The total number of developed meristems (84.5\%) and the higher number of the largest meristems more than $3 \mathrm{~mm}$ in size were noted at a concentration of $10.0 \mathrm{mg} / \mathrm{l}$. In this variant, a larger number of shoots were cut at the stage of proliferation. The concentration of $40 \mathrm{mg} / \mathrm{L}$ turned out to be toxic for the meristems and led to their complete death.

For the recovering from phytomycoplasma infection, the conclusion of the antibiotic Cefotaxime into the culture medium was studied. The preparations did not have a clear effect on the preservation of the meristems; however, it had a clear stimulating effect on the new shoots, especially in the variant with a concentration of $200 \mathrm{mg} / 1$.

In the Cabernet-Sauvignon variety, the addition of the growth regulator Melafen to the medium culture improved the formation of shoots (Table 2).

Table 2. The shoot formation with the various concentrations of Melafen, 2019

\begin{tabular}{|c|c|c|c|c|c|}
\hline \multirow{2}{*}{ Variants } & \multicolumn{5}{|c|}{ Formed shoots (pcs.) in the process of proliferation } \\
\cline { 2 - 6 } & 14.08 & 03.09 & 16.10 & 19.12 & total \\
\hline control & - & 1 & - & 1 & 2 \\
\hline $10^{-5}$ & 5 & - & - & 5 & 10 \\
\hline $10^{-7}$ & 10 & 3 & - & 14 & $\mathbf{2 7}$ \\
\hline $10^{-9}$ & - & 11 & 9 & 15 & $\mathbf{3 5}$ \\
\hline $10^{-11}$ & - & - & - & - & - \\
\hline Total per passage & 15 & 15 & 9 & 35 & 74 \\
\hline
\end{tabular}

In the control variant the single shoots were formed. The best result was noted at a concentration of 10-7 and especially 10-9. Thus, the growth regulator Melafen should be used to induce shoot formation.

The second part of our work was finding ways to slow growth for medium-term storage. To keep plants in a slowly growing collection, the initiation of sucrose into the culture medium in the concentration range of 10-90 g / L was studied [17]. The research have shown that in the cultivating grape varieties (Sibirkovy, Kukanovsky, Kosorotovsky, Tsimlyansky Cherny (clone 2-3), Varyushkin, Rupestris du Lot, Vierul) on the culture medium with the increased sucrose concentrations $(70-90 \mathrm{~g} / 1)$ the decrease in the growth rate was clearly manifested .

In addition to the high concentrations of sucrose in the culture media, we also have included minimum concentrationsof sucrose -5.0 and $10.0 \mathrm{~g} / \mathrm{l}$. In cultivated varieties under these conditions for 7 months, the decrease in growth processes was noted. During the study period, eight plants from the variant with a sucrose concentration of $5.0 \mathrm{~g} / 1,7$ plants from the variant with $20.0 \mathrm{~g} / 1$ and 11 plants from the variant with a concentration of $60.0 \mathrm{~g} / 1$ retained their viability.

We studied fructose as an alternative food source as the more efficient analog of sucrose. Studies have found that the initiation of fructose into the culture medium affects rhizogenesis and can stimulate or inhibit this process, and the growth and growth rate of shoots. Inhibition of shoot growth was noted after 3 months of cultivation. It was the most pronounced at the fructose concentrations of 20.0; 40.0 and $60.0 \mathrm{~g} / 1$. At the concentrations of 5.0 and $10.0 \mathrm{~g} /$ 1 , shoot growth approached the control. In the variant with a fructose concentration of $20.0 \mathrm{~g}$ / 1, the most developed rhizogenic zone and inhibition of plant growth were revealed.

One of the well-known osmotics is sorbitol. It has been proven that the long-term nonstop cultivation of the grape plants of the Agat Donskoy and Vostorg varieties was possible with the addition of sorbitol to the culture medium at a concentration of 5-10 g / 1 [18]. 
Moreover, plants were better preserved in a solid culture medium in the light, the decrease in growth processes was more significant in the liquid culture medium. During the cultivation in the dark, the growth of plants was inhibited, but along with this, there was large amount of death plants. Studies on plants of the Cabernet Sauvignon variety were carried out on a solid culture medium in the range of sorbitol concentrations 5-60.0 g/l. Starting from the fifth month of cultivation, the increase in plant growth was noted at a concentration of $5 \mathrm{~g} / \mathrm{l}$ and, especially at $7.5 \mathrm{~g} / \mathrm{l}$. In variants with a concentration of 10,30 and $60 \mathrm{~g} / \mathrm{l}$, the decrease in growth processes was observed during the entire cultivation period. The minimum plant length was recorded in the variant with the highest sorbitol concentration $-60 \mathrm{~g} / \mathrm{l}$.

\section{Conclusion}

For optimization of the initiation stage, we recommend to combine the apical meristems $0.1-$ $0.2 \mathrm{~mm}$ in size with using Ribavirin (5.0-10.0 mg / L), antibiotic Cefotaxime (200.0 mg / L), and growth regulator Melafen (10-7-10-9).

The varieties such as Platovskiy and Present were the most responsive to Ribavirin; on Cefotaxim - Crystal, North Saperavi, and Tsvetochniy; to Melafen - Cabernet Sauvignon and North Saperavi.

On the nutrient medium with a high $(60.0 \mathrm{~g} / 1)$ and low (5-10 g) sucrose content, it was possible to store plants directly for up to 270 days. Revealed inhibition of growth processes at the concentrations of sorbitol in the culture medium of 10-60.0 g/l and stimulation at the minimum concentration of the drug: 5.0-7.5 g / 1 . At fructose concentrations of 20.0; 40.0 and $60.0 \mathrm{~g} / 1$. the inhibition of shoot growth was observed. The use of sorbitol and fructose contributed to the extension of non-stop storage of grape plants up to 8-10 months.

\section{References}

1. F.K. Pilatti, T. Aguiar, T. Simões, et al. In Vitro Cell.Dev.Biol.-Plant 47, 82-98 (2011). https://doi.org/10.1007/s11627-010-9302-y

2. H. Barnicoat, R. Cripps, J. Kendon, V. Sarasan, In Vitro Cell. Dev. Biol. - Plant, 47, $37-$ 45 (2011). http://doi.org/10.1007/s11627-010-9303-x

3. C.A. Cruz-Cruz, M.T. Gonzalez-Arnao, F. Engelmann, Resources, 2(2), 73-95 (2013) http://doi.org/10.3390/resources2020073

4. M.A. Ramírez-Mosqueda, C.A. Cruz-Cruz, J. Atlahua-Temoxtle, J.J. Bello-Bello, S. African J. Bot., 121, 219-223 (2019). http://doi.org/10.1016/j.sajb.2018.11.010

5. M. Fallah, M. Farzaneh, M. Yousefzadi, M. Ghorbanpour, M.H. Mirjalili, Biocatal. Agric. Biotechnol., 17, 318-325 (2019) http://doi.org/10.1016/j.bcab.2018.12.010

6. A.A. Polulyakh, V.A. Volynkin, V.V. Likhovsko. Vavilov Journal of Genetics and Breeding, 21(6), 608-616 (2017) http://doi.org/10.18699/VJ17.276.

7. X.J. Pan, W.E. Zhang, X. Li, Vitis, 53(4), 207-214 (2014) https://doi.org/10.5073/vitis.2014.53.207-214

8. S. Tehrim, G.M. Sajid, Romanian Biotechnol. Lett., 16(6), 6781-6789 (2011) https://www.rombio.eu/rbl6vol16/13\%20Sadia\%20Tehrim.pdf

9. D. Dal Bosco, I. Sinski, V. Comachio, J.D.G. Maia, P.S. Ritschel, V. Quecini, ActaHortic.; 1082, 201-205 (2015) https://doi.org/10.17660/ActaHortic.2015.1082.27

10. D. Maghradze, R. Ocete, J.L. Garcia, M. Cantos, Vitis, 54 (Special Issue), 257-258 (2015) https://doi.org/10.5073/vitis.2015.54.special-issue.257-258

11. C.F. Popescu, E. Maul, L.C. Dejeu, D. Dinu, R.N. Gheorge, V. Laucou, T. Lacombe, D. Migliaro, M. Crespan, Vitis, 56(4), 173-180 (2017) https://doi.org/10.5073/vitis.2017.56. $\underline{173-180}$ 
12. E. Maul, R. Töpfer, F. Carka, V. Cornea, M. Crespan, M. Dallakyan, T. de Andrés Domínguez, G. de Lorenzis, L. Dejeu, S. Goryslavets, S. Grando, N. Hovannisyan, M. Hudcovicova, T. Hvarleva, J. Ibáñez, E. Kiss, L. Kocsis, T. Lacombe, V. Laucou, D. Maghradze, E. Maletić, G. Melyan, M.Z. Mihaljević, G. Muñoz-Organero, M. Musayev, A. Nebish, C.F. Popescu, F. Regner, V. Risovanna, S. Ruisa, V. Salimov, G. Savin, A. Schneider, N. Stajner, L. Ujmajuridze, O. Failla, Vitis, 54 (Special Issue), 5-12 (2015) https://doi.org/10.5073/vitis.2015.54.special-issue.5-12

13. A.I.A. Abido, M.A.M. Aly, Sabah Hassanen, \& Gamil Mohamed Middle East Journal of Scientific Research, 13, 328-337 (2013).https://doi.org/10.5829/idosi.mejsr.2013.13.3.19 $\underline{26}$

14. G. Zdunic, E .Maul, J.E. Eiras Diasetc at al., Vitis, 56 (3), 127-131 (2017) https://doi.org/10.5073/vitis.2017.56.127-131

15. J. C. Bettoni, R. Bonnart, A. Shepherd, A. A. Kretzschmar and G. M. Volk, Vitis, —58 (2), 71-78 (2019) https://doi.org/10.5073/vitis.2019.58.71-78

16.V. G. Puzirnova, N.P.Doroshenko Viticulture \& Winemaking 48, 40-42 (2019) https://www.elibrary.ru/download/elibrary 41203002_65168893.pdf

17. N.P. Dorocshenko, A.S. Kuprikova and V.G. Puzirnova, Fruit growing and viticulture of South Russia 46(4), 33-48 (2017)https://www.elibrary.ru/download/elibrary 29675151 15707070.pdf

18. N.P. Dorocshenko, V.G. Puzirnova Fruit growing and viticulture of South Russia 64(4), 190-209 (2020) https://doi.org 10.30679/2219-5335-2020-4-64-190-209 